\title{
Fenomena Gerakan Sosial Digital Mahasiswa Untirta Dengan Hastag \#UntirtaKokPelit di Twitter
}

\author{
Afifah Zulfika ${ }^{1}$ \\ Ilmu Pemerintahan, Universitas Sultan Ageng \\ Tirtayasa \\ zulfikaafifah@gmail.com \\ Yunus Sutejo ${ }^{2}$ \\ Ilmu Pemerintahan, Universitas Sultan Ageng \\ Tirtayasa \\ yunussutejo876@gmail.com
}

\author{
E-ISSN 2721-0642 \\ Article Info \\ Recieved: \\ July 292021 \\ Revised: \\ October 72021 \\ Accepted: \\ December 52021 \\ Doi Number \\ https://doi.org/10.37950/ijd.v3i3.99
}

\begin{abstract}
This research tries to see how digital social movements or digital movements carried out by UNTIRTA student voice their duties through online media during the pandemic period for the spread of the covid-19 virus. This research is important because it can see how social movements in a condition that do not support the gathering of people in a place but can still voice their entry. This study offers another approach in research because in this case it tries to see social movements due to limitations and becomes an alternative, but in other social movements it is done offline and directly in the field. Meanwhile, the focus of this research is on Sultan Agung Tirtauasa University, which is one of the public universities in Banten Province. This researcher sees the extent to which digital social movements can influence policy and become an alternative that is good or not used in situations like today.
\end{abstract}

Keywords: digital movement, alternative social movement, untirta.

\begin{abstract}
Abstrak
Penelitian ini mencoba melihat bagaimana gerakan sosial digital atau digital movement yang dilakukan oleh para mahasiswa UNTIRTA dalam menyuarakan tuntutannya melalui media secara online di masa pandemi untuk menghindari penyebaran virus covid-19. Riset ini menjadi penting karena dapat melihat bagaimana alternatif gerakan
\end{abstract}


sosial dalam suatu kondisi yang tidak memungkinkan berkumpulnya orangnya dalam suatu tempat namun tetap dapat menyuarakan tuntutannya. Penelitian ini menawarkan pendekatan lain dalam penelitian karena dalam hal ini mencoba melihat gerakan sosial digital karena suatu keterbatasan dan menjadi suatu alternaltif namun dalam gerakan sosial lainnya dilakukan secara offline dan secara langsung dilapangan. Sementara fokus dari riset ini adalah pada Universitas Sultan Agung Tirtauasa yang merupakan salah satu universitas negeri di Provinsi banten. Peneliti ini melihat sejauh mana gerakan sosial digital dapat mempengaruhi kebijakan dan menjadi suatu alternatif yang baik atau tidaknya digunakan dalam situasi seperti saat pandemi saat ini.

Kata Kunci: digital movement, alternatif gerakan sosial, untirta.

\section{Pendahuluan}

Gerakan sosial adalah pernyataan sikap dari masyarakat yang biasanya di tujukan kepada pemerintah atau pihak penguasa, melihat gejolak protes yang muncul, masyarakat dengan kepentingan dan keresahan yang sama secara masif tergerak untuk ikut menyuarakan keresahan mereka. Biasanya gerakan sosial muncul karena suatu kebijakan yang mengganggu harmonisasi hidup bermasyarakat atau mengganggu eksistensi masyarakat dan menguntungkan salah satu pihak saja. Mendengar kata gerakan saja kita sudah tergambar dengan aksi-aksi dijalan yang mana kita pada saat masuk kampus pasti dikenalkan dengan gerakan mahasiswa pada tahun 1998. Bentuk protes seluruh elemen masyarakat dan mahasiswa terhadap pemerintahan soeharto yang padasaat itu dirasa tidak demokratis di negara yang demokrasi ini. Akan tetapi gerakan sosial tidak melulu soal kekerasan fisik, turun ke jalan, protes langsung ke depan instansi, akan tetapi banyak sudah gerakan sosial baru yang memanfaatkan beberapa media di internet.

Perihal gerakan sosial sendiri dalam perkembangannya dengan arus globalisasi dan modernisasi yang pesat gerakan sosial mulai memasuki ruang digital. Dengan begitu, gerakan ssosial dalam ruang digital ini dapat membangun opini publik akibat adanya transformasi gerakan sosial pada media digital tersebut. Media digital dan media sosial pada akhirnya menjadi sebuah media baru untuk melakukan gerakan sosiial dan memberikan pengaruh besar sebagai pengawas dan pengkritik dunia informasi dan komunikasi yang tak terbatas ruang dan waktu. Pada akhirnya perkembangan media digital ini dijadikan sebagai sarana bagi mahasiswa UNTIRTA sebagai media baru untuk melakukan sebuah gerakan sosial dengan memanfaatkan media digital dalam memberikan opini dan menyuarakan haknya melalui media sosial.

Tulisan ini berisi mengenai fenomena gerakan sosial mahasiswa yang sampai sempat trending nomor 1 di twitter yang sama-sama kita ketahui platform twitter 126 juta pengguna aktif setiap harinya, hastag \#untirtakokpelit pun muncul di trending Indonesia twitter pada tanggal 12 Juni 2020. Seluruh Mahasiswa Universitas Sultan Ageng Tirtayasa pun ikut menggaungkan hastag untitra kok pelit tersebut guna 
menyuarakan protes terhadap rektorat Universitas Sultan Ageng Tirtayasa yang tidak menanggapi suara mahasiswa.

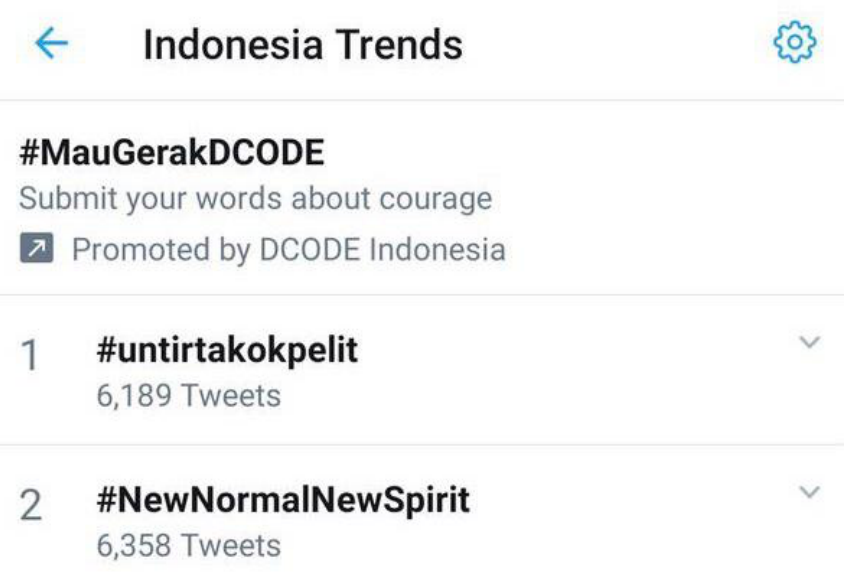

(Sumber: twitter, 2020)

Twitter dijadikan sarana untuk menyuarakan keresahan mahasiswa terutama mahasiswa yang sedang bergerak yaitu mahasiswa Untirta, karena di rasa momen yang sangat pas mengingat pada tanggal itu sedang gemparnya kasus Covid-19 yang kian meningkat setiap harinya. Larangan gerakan mahasiswa yang diselenggarakan di jalanpun dihimbau oleh pemerintah untuk tidak berkerumun secara masif. Gerakan sosial ini menjadi gerakan sosial baru yang mana gerakan tidak diselenggarakan secara fisik namun di era digital ini yang mana mahasiswa bukan memprotes kebijakan pemerintah, akan tetapi mahasiswa untirta yang merasa suaranya tidak di dengar oleh pihak rektorat meluapkan suaranya di media sosial terhadap kepentingan sesama. Hal ini juga menjadi sebuah transformasi gerakan sosial yang pada mulanya pada ranah fisik berubah kepada ranah digital. Melalui media digital ini maka dapat dijadikan sebagai media komunikasi dan media perlawanan dari mahasiswa untirta dalam menyuarakan haknya. Akan tetapi, dalam hal ini tetap terdapat strategi dalam menggerakan massa di media sosial tersebut. Gerakan sosial melalui media digital ini dianggap lebih efisien dalam menggerakan massa perlawanan karena dapat dengan cepat menyebarkan informasi secara luas dengan biaya yang murah.

Keadaan pada saat pandemi mendesak semua mahasiswa untuk menekan pengeluaran finansial dengan melihat sebagian keluarga dari mahasiswa di PHK dari pekerjaannya dengan alasan pandemi covid-19, di masa pandemi ini pun menjadi tuntutan mahasiswa terhadap permintaannya kepada pihak rektorat dalam protes penurunan uang kuliah tunggal di untirta. Sudah di lakukan beberapa kali audiensi dilaksanakan prihal tuntutan penurunan UKT dari pihak BEM KBM Untirta (Badan Eksekutif Mahasiswa Keluarga Besar Mahasiswa Universitas Sultan Ageng Tirtayasa) kepada rektorat namun tidak menemui titik temu, pihak kampus menyatakan mereka masih menunggu kebijakan kampus lain, sedangkan kampus yang sudah mengeluarkan kebijakan potongan ukt itu rata-rata kampus swasta, sedangkan untirta 
adalah kampus negeri, yang kebijakannya juga melihat Kemendikbud yang pada saat itu juga belum mengambil sikap, sehingga konsolidasi dari berbagai elemen mahasiswa untirta pun dilakukan hampir setiap minggu secara offline maupun online, konsolidasi juga bukan hanya internal kampus akan tetapi konsolidasi dilaksanakan juga mengajak eksternal luar kampus yang ada kaitannya dengan kampus, seperti PWNU, Rektor yang menjabat sebelumnya, komunikasi eksetrnal ini dibangun guna mendiskusikan terkait kebijakan secara tertulis.

Tulisan ini akan membahas mengenai bagaimana gerakan sosial digital yang dilakukan secara online oleh para mahasiswa UNTIRTA pada masa pandemi dalam menyuarakan haknya atas tuntutan penurunan UKT dan beberapa tuntutan lainnya dalam mendapatkan sebuah perubahan atas gerakan tersebut.

\section{Kerangka Teori}

\section{Gerakan sosial}

Gerakan sosial didefinisikan sebagai suatu upaya yang dilakukan oleh sekumpulan orang untuk dapat menentang suatu hal yang menjadi permasalahan dalam kehidupan bermasyarakat. Menurut Martono (2015), gerakan sosial memiliki makna sebagai suatu gerakan yang muncul dari sekelompok orang yang memiliki tujuan yang sama demi memperjuangkan aspirasi, tuntutan dan kepentingan untuk sebuah perubahan kepada pihak tertentu. Lahirnya gerakan sosial dalam masyarakat ini diakibatkan karena beberapa hal salah satunya adalah karena adanya ketidakadilan dan keresahan yang terjadi dimasyarakat. Dengan begitu, gerakan sosial ini juga termasuk kepada salah satu tindakan kolektif. Hal tersebut juga sesuai dengan definisi menurut Giddens (2006) yang mana gerakan sosial merupakan upaya kolektif yang dilakukan melalui tindakan kolektif demi mencapai tujuan bersama. Umumnya, seseorang dapat berpartisipasi dalam tindakan kolektif tersebut dikarenakan ingin mengungkapkan kemarahannya kepada target yang telah melanggar nilai yang ada.

Dalam gerakan sosial ini tentunya dilakukan dan diperjuangkan untuk memperoleh sebuah perubahan atas keresahan yang terjadi. Maka dari itu, gerakan sosial diartikan sebagai sekumpulan orang yang melakukan tindakan bersama secara terorganisir dan tidak melembaga untuk dapat membawa suatu perubahan di masyarakat, Stompzka dalam (Hapsari, 2016). Perubahan sosial dapat dinilai sebagai suatu produk dari gerakan sosial atas transformasi yang telah dilakukan.

Pada kategori yang lebih umum, menurut Tarrow gerakan sosial ditempatkan sebagai hal yang bernilai pada politik perlawanan (Hapsari, 2016). Politik perlawanan yang dimaksud disini adalah sebuah gerakan sosial dengan penentangan dan revolusi yang dilakukan. Dalam kondisi ini, masyarakat sebagai rakyat biasa melakukan konsolidasi dengan yang lebih berpengaruh untuk membuat sebuah kekuatan dalam melawan para penguasa yang memegang otoritas serta para pihak lain sebagai lawannya. 
Perihal gerakan sosial, terdapat suatu teori dalam melaksanakan sebuah gerakan yaitu melalui tiga cara. Pertama, dengan melakukan melalui teori mobilisasi sumber daya yang mana dalam teori ini gerakan sosial akan dinilai berhasil jika memiliki jaringan organisasi yang kuat dalam melibatkan banyak massa dan juga memiliki uang. Kedua, dengan menggunakan teori struktur kesempatan politik yang mana gerakan sosial akan dinilai berhasil jika adanya opputurnity atau kesempatan yang dinilai tepat. Kesempatan yang dimaksud disini adalah perubahan dalam struktur politik yang terjadi akibat gerakan sosial. Ketiga, dengan menggunakan teori frame yang mana gerakan sosial disini akan dinilai berhasil jika aktor yang berperan dapat membentuk suatu isu yang menyentuh. Tentunya dalam hal ini akan berkorelasi dengan para aktor perubahan untuk dapat mempengaruhi makna kebijaksanaan publik. Dari ketiga hal tersebut maka dapat dinilai sebagai suatu strategi gerakan sosial dalam melakukan aksi bersama.

Perihal gerakan sosial sendiri menurut Alan Touraine dan Alberto Melucci diklarifikasikan menjadi dua yaitu, gerakan sosial lama (Old Social Movement) dan gerakan sosial baru (New Social Movement). Jika dilihat secara mendasar, Old Social Movement lebih kepada hal yang menyangkut materi/uang yang dapat dipertukarkan untuk kepentingan suatu kelompok saja seperti kelompok buruh maupun petani. Kemudian jika melihat New Social Movement lebih kepada isu yang berkaitan dengan nilai dalam konteks yang terbilang cukup luas serta tidak dapat dipertukarkan seperti, isu lingkungan, budaya, identitas, gender, dsb.

Jika dilihat lebih dalam, menurut Suharko gerakan sosial terbagi menjadi beberaoa bentuk. Pertama, gerakan protes yang mana dalam gerakan ini memiliki tujuan dalam menentang suatu kondisi dan bentuk gerakan ini merupakan gerakan paling umum yang serung terjadi. Kedua, gerakan regresif yang mana gerakan ini memiliki tujuan dalam menentang atau menolak gerakan protes dan membalikan perubahan sosial. Ketiga, gerakan religius yang mana gerakan ini berkorelasi dengan isu spiritual dan supernatural dalam menentang hal hal yang berkaitan dengan aspek agama (Suharko, 2006).

Pada intinya gerakan sosial ini merupakan suatu gerakan dalam bentuk koletif yang mana terdapat sekumpulan orang yang memiliki suatu kereasahan dengan mengharapkan terjadinya sebuah perubahan. Bahkan gerakan sosial sendiri menurut Martono dalam (Hardianto, 2020) lahir karena sekumpulan individu dalam suatu kelompok yang memiliki keinginan dalam memperjuangkan kepentingan dan aspirasi bersama dengan car menuntut adanya sebuah perubahan terhadap kelompok penguasa tertentu.

\section{Gerakan Sosial Digital}

Dalam perkembangannya gerakan sosial seringkali mengalami perkembangan dari tahun ke tahun. Bahkan dalam 10 tahun terakhir gerakan sosial mulai mengikuti arus modernisasi dan globalisasi dengan melibatkan gerakan sosial kepada ruang digital. Dalam beberapa tahun terakhir, sebenarnya pemanfaat teknologi dan mendia 
telah dilakukan untuk dapat menghimpun gerakan sosial. Upaya keinginan melakukan gerakan sosial diawali karena adanya kesamaan tujuan, dan keinginan. Hal tersebutlah yang pada akhirnya menjadikan sebuah ketertarikan membangunan opini publik dan melakuakn gerakan sosial dengan keterlibatan ruang digital (Nur Hasanah, 2017).

Perihal ruang digital sendiri pada hakikatnya tidak selalu dapat menciptakan wacana. Akan tetapi, hal tersebut dapat menjadi suatu alternatif untuk menjadi otoritas tertentu. Dalam media digital sendiri memiliki sebuah kekuatan dan memberikan pengaruh yang cukup besar karena dengan cepat terhubung langsung kepada seluruh belahan di dunia Astuti dalam (Nur Hasanah, 2017). Masyarakat sendiri dapat mengangkat beberapa isu permasalahan yang hangat melalui media digital serta menyarakan pendapatnya dengan melakukan gerakan sosial tertentu.

Mengenai gerakan sosial digital sendiri dikatakan lahir karena adanya suatu perkembangan teknologi yang salah satunya adalah media sosial. Digital Movement atau gerakan sosial digital ini dapat dikatakan sebagai mobilisasi online massa dalam memberikan suatu reaksi terhadap suatu isu permasalahan tertentu yang memberikan keresahan bagi masyarakat Airoldi dalam (Prihantoro et al., 2021) Gerakan sosial digital ini dinilai sebagai gerakan sosial yang spontan dan bahkan dinilai sebagai kombinasi dari konsep antara sosial dan opini publik.

Penggunaan media digital dalam gerakan sosial sendiri menurut Nugroho dalam dinilai lebih efektif karena dapat dilakukan dengan kurun waktu yang relatif singkat dalam memperoleh banyak dukungan dari pada pengguna media digital khususnya pengguna media sosial dalam melakukan suatu gerakan sosial digital tersebut. Penilaian penggunaan media sosial sebagai alat gerakan sosial yang efektif dapat dibuktikan dengan adanya perilaku masa yang berpartisipasi dengan dilatar belakangi atas gerakan sosial tersebut secara online (Prihantoro et al., 2021). Gerakan yang dilakukan secara online tersebut dilakukan hingga membentuk kebiasaan dan kebutuhan menjadi warga digital atau yang biasa disebut dengan digital citizen atau warga digital. Warga digital adalah salah satu aspek dari evolusi kontemporer yang lebih besar dari sosok warga negara, evolusi yang bergerak menjauh dari warga negara yang sudah memiliki hak menuju warga negara sebagaimana dibentuk melalui tindakan (Evelyn Ruppert \& Engin Isin, 2020). Menurut mereka manusia membentuk dunia maya itu sendiri, serta diri mereka sendiri sebagai warga digital, dengan mengatakan dan melakukan sesuatu. Suatu tindakan, khususnya tuntutan hak, berdampak melalui kekuatan konstitutif kekuatan performatif, hukum, dan imajiner. Tak hanya itu, menjadi Warga Digital memberikan kontribusi kerangka kerja konseptual yang bernuansa, fleksibel, seputar aktivitas politik kontemporer, terutama yang berlangsung melalui internet

Dalam Digital Movement terdapat beberapa hal yang mencirikan gerakan sosial digital menurut Barisione \& Cero (2017). Pertama, bersifat impulsif dan tidak teratur. Kedua, gerakan sosial digital umumnya berdurasi tidak lama. Ketiga, pendapat dan opini massa umumnya bersifat lebih homogen. Keempat, Terdapay banyak sektor yang terlibat sehingga terdapat lintas sektor (Prihantoro et al., 2021) Dalam konsep gerakan sosial digital pun terdaoat beberaoa hal teoritis yang dinilai menjadi dimensi digital 
dalam keterlibatan masyarakat dan upaya menghubungkan ipini publik dan juga gerakan sosial yang akan dikembangkan melalui tindakan kkolektif yang lebih berjejaring.

Mengenai gerakan sosial gital sendiri media sosial dijadikan sebagairuang publik untuk dapat bergerak dengan waktu yang singkat pada dunia modern ini. Hal ini pada akhirnya dijadikan strategi gerakan bagi masyarakat modern maupun mahasiswa melalui media sosialnya untuk terlibat dalam suatu gerakan sosial. Menurut Benford \&Show, terdapat tiga hal yang menjadi suatu unsur pokok dalam gerakan sosial. Pertama, gerakan sosial dilakukan atas dasar tujuan yang sama. Kedua, gerakan sosial dilakukan secara koletif dengan tujuan dan kepentingan kolektif juga. Ketiga gerakan sosial memiliki keinginan atas sebuah perubahan (Nur Hasanah, 2017).

Perihal media digital sendiri yang salah satunya adalah media sosial twitter dijadikan sebagai alat gerakan sosial dalam menyalurkan opini para pengguna media sosial melalui digital. Media sosial twitter juga menjadi suatu sarana yang dinilai lebih efisien dan tepat karena dapat menyampaikannya secara langsung kepada pihak yang ingin ditujukan Dalam melakukan gerakan sosial pada media sosial twitter para pengguna yang terlibat menggunakan hastag dalam gerakannya untuk membentuk suatu opini dalam satu kelompok. Hastag merupakan salah satu media yang digunakan dalam aktivitas digital yang memberikan saran dan tagar untuk dapat melihat emosional dan imajinasi naratif dalam ranah digital Para pengguna dapat menunjukan sikap setuju atau tidaknya terhadap suatu isu permasalahan yang sedang diangkat serta dapat mengupload komentarnya disertai dengan tagar tertentu (Prihantoro et al., 2021).

Pada hakikatnya gerakan sosial melalui media sosial ini merupakan salah satu kebangkitan dari masyarakat sipil dengan melihat kembali pengguna media sosial di Indonesia merupakan pengguna terbesar ke-4 didunia. Gerakan sosial digital dapat menjadi suatu alternatif dalam mengikuti keterlibatan dalam gerakan sosial unruk dapat berkontribusi menyuarakan hak dan opininya (Ismail, Ahmad., 2019). Secara teoritis menurut Darmawan terdapat beberapa aspek yang akan menjadi suatu penentu dalam sebuah keberhasilan pada gerakan sosial (Kalabahu, 2018):
a. Adanya pemimpin
b. Adanya artikulasi ysng jelas perilah gagasannya yang merepresentasikan kepentingan bersama
c. Adanya ekskalasi atau pertambahan konstituen
d. Adanya sumber daya manusia maupun sumber daya finansial

\section{Metode Penelitian}

Pada penulisan ini data yang dipakai dari Naskah ini yang memuat Fenomena Gerakan Sosial Digital Mahasiswa Untirta dengan Hastag \#Untirtakokpelit di Twitter dengan menggunakan metode penelitian kualitatif serta analisis terhadap sumber data Primer dan Sekunder yang didapat dari beberapa sumber langsung berupa wawancara kepada narasumber terkait dan dokumen dari media beberapa laman website di internet kemudian diituliskan secara deskriptif. Penulisan naskah ini melakukan 
pengumpulan data menlalui studi pustaka atau literature review serta data lapangan. Sehingga memunculkan apa yang terjadi dilapangan secara sistematis akurat serta faktual.

\section{Hasil dan Diskusi}

Pandemi covid-19 telah hadir dalam kehidupan kita sejak maret tahun lalu. Problematika pandemi yang merambah di Indonesia dengan penyebarannya yang sangat cepat dan tingkat positif covid-19 yang terus meningkat maka pemerintah mengambil suatu langkah alternatif yang dilakukan pada saat itu. Dengan permasalahan pandemi tersebut pemerintah pada akhirnya melakukan penanggulangan dengan menerapkan kebijakan Pembatasan Sosial Berskala Besar (PSBB) di beberapa wilayah dan menerapkan pesan untuk tetap dirumah dan berjaga jarak. Pembatasan yang dilakukan tersebut pada akhirnya membuat segala aktivitas dan kegitan menjadi terhambat bahkan sekolah dan kuliah dilakukan secara online dan pekerja melakuakn pekerjaannya dnegan sistem work from home. Tempat hiburan, sekolah, kantor, pusat perbelanjaan dibatasi. Hal tersebut tentunya akan berpengaruh kepada pendapatan dan perekonomian Indonesia.

Pendapatan dan perekonomian Indonesia yang semakin menurun dan tidak memandang bulu dalam arti pengusaha, pemilik perubahan mengalami dampaknya belum lagi seseorang yang memiliki pekerjaan harian seperti driver ojek online, dll. Karena penurunan perekonomian tersebut tidak memandang bulu maka banyak perusahaan yang tidak dapat membayar karyawannya sehingga mau tidak mau melakukan PHK (Pemutusan Hubungan Kerja) kepada sebagain pekerjanya. Berdasarkan data yang diberikan oleh Ida Fauziyah selaku Menteri Ketenagakerjaan perusahaan yang melakukan PHK selama pandemi dapat terhitung sebanyak 17,8\%. Tak hanya itu, terdapat perubahsaan yang merumahkan karyawannya sebanyak 25,6\% dan juga terdapat perusahaan yang melakukan keduanya sebanyak 10\% (Sulaeman, 2021). Dan pada sektor informal lainnya yang tentunya memerlukan perhatian khusus dalam kondisi perekonomian yang semakin berat karena tekanan pandemi yang terjadi.

Dengan permasalahan yang terjadi pada masa pandemi hingga banyaknya yang terkena PHK, maka hal tersebut berpengaruh kepada upaya pembayaran uang kuliah semester mahasiswa. Hal tersebut dikarenakan terdapat sebagaian mahasiswa yang mana orang tuanya terkena dampak PHK ataupun pekerja sektor informal yang pada akhirnya membuat perekonomiannya semakin berat. Maka dari itu, dengan kondisi yang perekonomian yang menurun ini mahasiswa membutuhkan pemotongan UKT (Uang Kuliah Tunggal) untuk dapat terus melanjutkan perkuliahannya. Hal tersebut juga karena beberapa fasilitas kampus tidak digunakan mengingat perkuliahan dilaksanakan secara daring. Namun disatu sisi dengan pelaksanaan kuliah secara daring tersebut mahasiswa memutuhkan subsidi kuota kuliah demi menunjang pembelajaran. Karena perkuliahan secara daring akan memakan banyak kuota dan biaya yang tentunya akan memberatkan bagi mahasiswa khususnya mahasiswa Untirta. 
Melalui berbagai keresahan yang dimiliki oleh para mahasiswa dalam masa pandemi tersebut. Mahasiswa sebagai pihak yang memiliki keresahan sekaligus dinilaai sebagai agent of change tersebut pada akhirnya melakukan sebuah aksi atau gerakan demi dapat mencapai tujuan yang dibutuhkan. Gerakan yang dilakukan oleh mahasiswa tersebut dilaksanakan secara daring melalui berbagai media sosial seperti salah satunya adalah melalui twitter. Gerakan yang dilakukan melalui media sosial tersebut dinamakan sebagai gerakan digital. Gerakan tersebut dilakukan untuk memutuskan rantai penyebaran covid-19. Berikut merupakan gerakan yang dilakukan oleh salah satu mahasiswa melalui twitter dengan hastag \#Untirtakokpelit

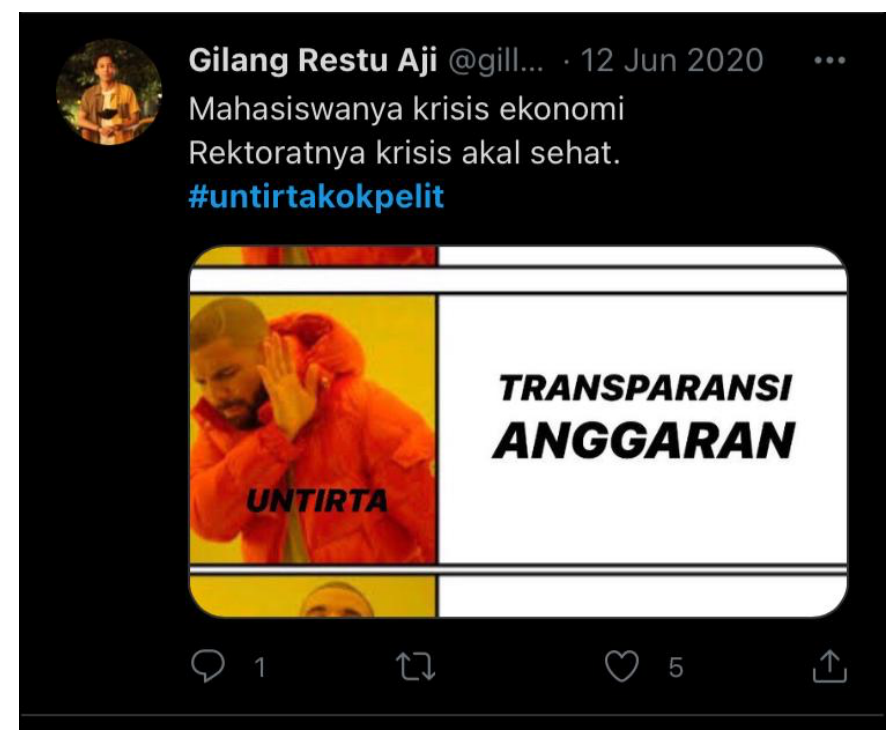

(Sumber: Twitter, 2021)

Berdasarkan gambar berikut dapat dilihat bahwasanya terdapat gerakan yang dilakukann melalui media sosial dengan hastag \#untirtakokpelit. Dengan melihat situasi pandemi yang pada saat itu masih hangat muncul di Indonesia maka mahasiswa melakukan gerakan tersebut melalui media. Namun pengaruh media cukup kuat hingga pada saat itu hastag \#untirtakokpelit mencapai tranding 1 di Indonesia. Gerakan yang dilakukan secara online tersebut dilakukan hingga membentuk kebiasaan dan kebutuhan menjadi warga digital atau yang biasa disebut dengan digital citizen atau warga digital. Sesuai dengan teorinya, warga digital adalah salah satu aspek dari evolusi kontemporer yang lebih besar dari sosok warga negara, evolusi yang bergerak menjauh dari warga negara yang sudah memiliki hak menuju warga negara sebagaimana dibentuk melalui tindakan (Evelyn Ruppert \& Engin Isin, 2020). Gerakan sosial yang dilakukan melalui media sosial dengan hastag \#untirtakokpelit tersebut juga sesuai dengan pendapat menurut mereka yang mana manusia membentuk dunia maya itu sendiri, serta diri mereka sendiri sebagai warga digital, dengan mengatakan dan melakukan sesuatu. Berikut merupakan beberapa akun yang paling sering muncul dalam gerakan digital mahasiswa Untirta dengan Hastag \#Untirtakokpelit 


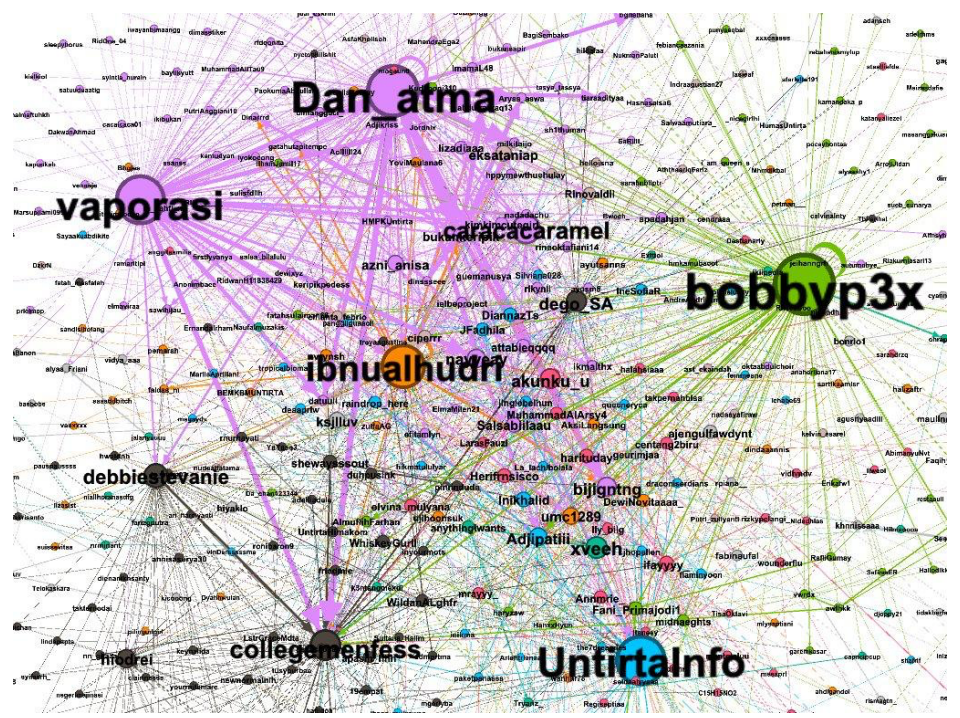

(Sumber: Twitter, 2020)

Berdasarkan gambar tersebut bisa terlihat bahwasanya terdapat akun-akun yang seringkali muncul dalam melakukan sebuah gerakan digital melalui twitter untuk menuntut suatu kepentingannya dengan pelibatan media sosial hingga dapat mendapati tranding topik 1 Indonesia. Selain itu terdapat beberapa tweet yang seringkali muncul pada saat itu yang sesuai dengan hastag \#untirtakokpelit.

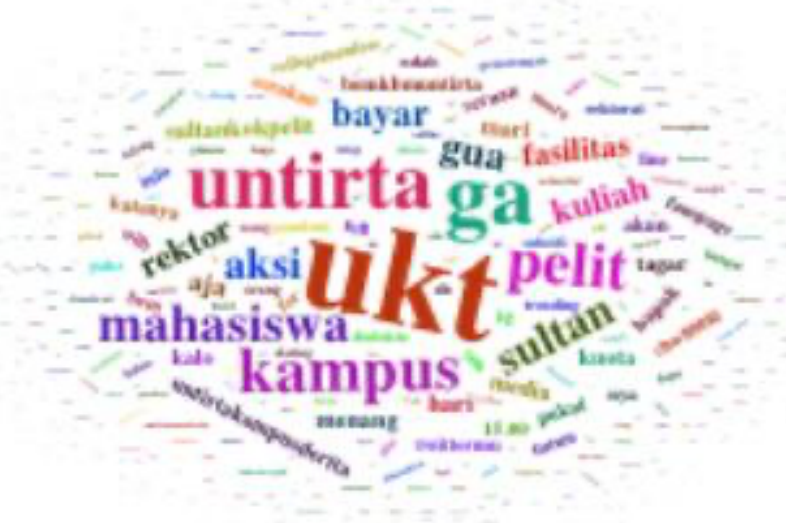

(Sumber: Twitter, 2020)

Dengan beberapa hal tersebut, bisa dikatakan bahwa gerakan sosial yang dilakukan oleh mahasiswa Untirta dalam menuntut apa yang menjadi kebutuhannya saat itu tetap dapat dilakukan sekalipun pandemi dan penyebaran virus yang sangar cepat. Gerakan sosial yang dilakukan oleh mahasiswa Untirta tersebut dilakukan dengan memanfaatkan teknologi dan media sosial sebagai media baru dalam melakukan sebuah gerakan. 


\section{Tuntutan Dan Perlibatan Pihak Ekseternal Dalam Gerakan}

Beberapa waktu sebelum aksi tersebut pihak dari BEM KBM Untirta menjalin komunikasi terhadap beberapa pihak di internal maupun di eksternal. Pada komunikasi Internal Wakil Rektor 2 yaiu bidang Keuangan kemudian telah menyetujui hal yang menjadi tuntutan mahasiswa pada saat itu kemudian setelah itu terjalin juga komunikasi antara mahasiswa dengan Rektor yang menjabat pada saat itu, dalam diskusi itu berjalan dengan kondusif sampai akhirnya perdebatan dan keluar satu kata yang menjadi senjata bagi mahasiswa yaitu rektor meminta pertukaran posisi sebagai press BEM bila ingin mahasiswa dipenuhi tuntutannya, dari kata kata tersebut muncul lah teori musuh bersama yang dibawa mahasiswa agar aksi massa mempunyai satu target dalam gerakan yaitu sikap rektor yang demikian.

Konsolidasi atau pembicaraan bersama mengenai persoalan apa yang akan dibawa kedalam gerakan sosial diperlukan, karena segala macam tuntutan dari aksi massa harus disebarkan demi substatifnya gerakan tersebut menjadi gerakan yang terorganisir. Setelah BEM KBM Untirta pada sabtu 6 Juni 2020 mengadakan konsolidasi akbar yang diadakan via Zoom Meeting kepada teman teman mahasiswa serta Keluarga Besar Mahasiswa di tiap tiap Fakultas yang dihadiri oleh Fakultas Ekonomi dan Bisnis, Fakultas Kedokteran, Fakultas Hukum, Fakultas Teknik, Fakultas Keguruan dan Ilmu Pendidikan, Fakultas Ilmu Sosial dan Ilmu Politik, Fakultas Pertanian. Dari bebrapa usulan dan saran pada konsolidasi akbar 1 yang diselenggarakan BEM Keluarga Besar Mahasiswa Untirta yang pada akhirnya menghasilkan beberapa Pandangan umum mahasiswa mengenai konsolidasi terhadap gerakan ini diantaranya:

1. Surat Edaran yang dikeluarkan pihak rektorat tidak pro terhadap mahasiswa karena adanya diskriminasi.

2. Penyesuaian UKT pada masa pandemi harus segera terlaksana.

3. Harus ada transparasi terhadap penyesuaian UKT mahasiswa dalam penggunaannya pada masa pandemi.

4. Arah gerak harus sistematis dan massif.

5. Perumusan mengenai arah gerak selanjutnya .

6. Pembebasan UKT walaupun hanya beberapa golongan juga tidak masalah dengan mengkomparasikan terhadap kebijakan kampus lain.

7. Edukasi pada setiap mahasiswa perlu dilakukan mengenai informasi UKT dan arah gerak selanjutnya.

8. Mekanisme penurunan UKT sudah pernah dilakukan oleh karena itu perlu adanya kebijakan baru dan khusus pada masa pandemi ini.

Dari beberapa pandangan umum yang sudah di uraikan melalui notulensi dari konsolidasi Akbar yang dilaksanakan oleh BEM KBM Untirta beserta semua Fakultas yang berada di Untirta, Ketua BEM KBM Untirta pada saat itu melakukan komunikasi eksternal kepada beberapa pihak terkait kebijakan secara legal yang akan dibawa kepihak rektorat. Kemudian setelah menjalin komunikasi secara eksternal tuntutan yang dibawa oleh Mahasiswa Unirta pada saat itu mendapatkan dukungan dari 
Gubernur Banten, PWNU, Rektor yang menjabat sebelumnya, kemudian mahasiswa juga menjalin komunikasi kepada Lembaga Hukum guna membentengi mahasiswa terhadap ancaman ancaman yang ditimbulkan karena aksi tersebut, lembaga hukum yang siap menaungi mahasiswa aksi \#untirtakokpelit yaitu ada LBH (Lembaga Bantuan Hukum) Rakyat Banten, kemudian dari Bantuan Hukum Probono secara pribadi. Karena sempat terjadi ancaman kepada salah satu mahasiswa khususnya mahasiswa yang mendapatkan program beasiswa bidikmisi dengan ancaman berupa pencabutan beasiswa bidikmisi bila mengikuti aksi tersebut. Terjadi intimidasi terhadap mahasiswa tersebut dari pihak kampus dengan menanyakan soal gerakan \#untirtakokpelit.

\section{Produk Gerakan Digital Mahasiswa Untirta Dalam Hastag \#Untirtakokpelit}

Gerakan digital mahasiswa Untirta dalam memperjuangkan kepentingannya sesuai dengan tuntutan yag dibawa pada akhirnya menemukan titik terang. Setelah mendapati surat edaran sebelummnya mengenai pembelajaran daring kepada mahasiswa yang dikeluarkan Kementerian Pendidikan dan Kebudayaan Direktorat Jenderal Pendidikan Tinggi, maka pada tanggal 13 april 2020, para pimpinan ormawa fakultas dan universitas melakukan pertemuan dengan pihak rektorat yaitu WR 3 melalui zoom. Dengan pertemuan yang dilakukan tersebut maka hasil dari rapat pimpinan tersebut mengeluarkan kebijakan mengenai mekanisme subsidi kuota dengan besaran Rp.50.000 perbulan. Hal tersebut juga sesuai dengan keputusan yang dikeluarkan oleh rektor Untirta dengan nomor 317/UN43/KPT.KM.01.01/2020 perihal pemberian subsidi kepada mahasiswa aktif dalam pembelajaran daring di lingkungan Untirta.

Berdasarkan gerakan yang telah dilakukan oleh mahasiswa Untirta tersebut kemudian menghasilkan suatu produk yang mana mendapatkan subsidi pulsa sebanyak Rp.50.000 perbulan sesuai dengan keputusan rektor. Selain itu, subsidi pulsa yang diberikan tersebut dalam keputusannya tidak hanya diberlakukan untuk mahasiswa tertentu saja namunn juga diberlakukan untuk mahasiswa aktif kuliah. Kemudian produk gerakan digital yang kedua adalah adanya penggunaan mengenai prioritas angara dalam kepentingan mahasiswa yang mana hal tersebut diberikan pemotongan UKT kepada seluruh Mahasiswa untirta sebanyak Rp.300.000. Kedua produk yang dihasilkan dalam gerakan digital tersbeut tentunya sangat bermanfaat bagi mahasiswa Untirta terlebih yang sedang membutuhkan dan dalam situasi darurat.

Keberhasilan dalam gerakan digital pada hastag \#untirtakokpelit tersebut dapat dikaitkan dengan teori mengenai keberhasilan gerakan sosial menurut Dawrmawan (Kalabahu, 2018) yaitu:

a. Adanya pemimpin

Adanya kepemimpinan disini adlah adanya seseorang yang menjadi pemimpin untuk memimpin dan mengarahkan alur gerakan yang terjadi dan mengatur strateginya bersama-sama. Seperti halnya dalam gerakan digital pada hastag \#unirtakokpelit terdapat beberapa pimpinan ormawa fakultas dan universitas yang turut mengawal permasalahan dan tunutan yang dibawa 
b. Adanya artikulasi yang jelas perihal gagasan dan merepresentasikan kepentingan yang sma

Dalam gerakan ini terlihat secara jelasn perihal gagasan dan tuntutan yang dibutuhkan dan dibawa seperti dalam menghaadapi kondisi pandemi dan perekonomian yang semakin menurut maka perlu adanya penurunan ukt dan pemberian subsidi kuota.

c. Adanya pertambahan atau ekskalasi konstituen atau hal yang penting

d. Adanya sumber daya manusia dan sumber daya finansial.

Sumber daya ini manusia yang dimaksud disini adalah para partisipasi yang turut terlibat dalam melakukan sbuah gerakan dan menyampaikan berbagai tuntutan yang dimiliki. Namun dalam kasus ini sumberdaya finansial tidak menentukan keberhasilan dalam suatu gerakan tersebut karena gerakan digital dapat diakses dengan mudah dan siapapun dapat mengaksesnya.

\section{Kesimpulan}

Jadi penulis menyimpulkan bahwa pada gerakan ini komunikasi yang dibangun secara ekseternal dengan beberapa pihak juga penting diantaranya yang dijalin oleh para mahasiswa yaitu Lembaga Bantuan Hukum, Pemerintah Provinsi, PWNU, serta pihak pihak lainnya yang ikut mendukung gerakan atas tuntutan prihal UKT di Untirta. Terlihat bahwa terdapat satu mahasiswa yang dapat ancaman berupa pemberhentian beasiswa oleh pihak kampus, namun jika itu terjadi pihak eksternal terutama Lembaga Bantuan Hukum bisa memfasilitasi teman teman mahasiswa untuk memperjuangkan haknya dalam berpendapat. Fenomena gerakan sosial dengan basis digital pada platiform Twitter yang dilakukan mahasiswa untirta membuahkan hasil yang mana produk dari fenomena gerakan hastag \#untirtakokpelit di twitter ini menghasilkan dua kebijakan yang dikeluarkan oleh pihak Rektorat diantaranya:

1. pada tanggal 13 april 2020, para pimpinan ormawa fakultas dan universitas melakukan pertemuan dengan pihak rektorat yaitu WR 3 melalui zoom. Dengan pertemuan yang dilakukan tersebut maka hasil dari rapat pimpinan tersebut mengeluarkan kebijakan mengenai mekanisme subsidi kuota dengan besaran Rp.50.000 perbulan.

2. adanya penggunaan mengenai prioritas angara dalam kepentingan mahasiswa yang mana hal tersebut diberikan pemotongan UKT kepada seluruh Mahasiswa untirta sebanyak Rp.300.000.

\section{Tentang Penulis}

Afifah Zulfika adalah mahasiswa Ilmu Pemerintahan, FISIP, Untirta. salah satu kajian yang diminati adalah Gender Equity.

Yunus Sutejo adalah mahasiswa Ilmu Pemerintahan, FISIP, Untirta. Ketertarikan riset terhadap kepemimpinan pemerintahan dan Perjuangan Hak Asasi Manusia. 


\section{Ucapan Terimakasih}

Ucapan terima kasih yang bertama yaitu kepada Allah SWT Karena rahmatnya penulis dapat menyelesaikan penulisannya dengan tema "Fenomena Gerakan Sosial Digital" serta penulis menyadari bahwa naskah ini masih jauh dari kata sempurna, apabila terdapat kekeliruan pada naskah ini kami mohon maaf sebesar besarnya. Penulis juga mengucapkan terimakasih kepada pihak terkait diantaranya, M. Dian Hikmawan selaku dosen pengampu mata kuliah gerakan sosial politik, serta teman teman mahasiswa Untirta yang menjadi narasumber pada penelitian ini. Semoga kedepannya Jurnal ini dapat bermanfaat terhadap penelitian lainnya yang memiliki tema yang sama.

\section{Referensi}

Evelyn Ruppert \& Engin Isin. (2020). Being Digital Citizens. Rowman \& Littlefield.

Hapsari, D. R. (2016). Peran Jaringan Komunikasi Dalam Gerakan Sosial Untuk Pelestarian Lingkungan Hidup. Jurnal Komunikasi Ikatan Sarjana Komunikasi Indonesia, 1(1), 25-36. https:// doi.org/10.25008/jkiski.v1i1.33

Hardianto, F. (2020). Gerakan sosial - politik (studi kasus : gerakan sosial \#2019gantipresiden ) .

Ismail, Ahmad., D. (2019). Online Social Movement: Adopsi Teknologi Informasi dalam Melakukan Gerakan Sosial. Jurnal Etnografi Indonesia, 4(1), 91-114.

Kalabahu. (2018). Mendefinisikan Gerakan Sosial dan Tantangannya. LBH Jakarta. https:// bantuanhukum.or.id/mendefinisikan-gerakan-sosial-dan-tantangannya/

Nur Hasanah, A. (2017). Transformasi Gerakan Sosial Di Ruang Digital. Jurnal Pendidikan Sosiologi.

Prihantoro, E., Rakhman, F. R., Ramadhani, R. W., \& Gunadarma, U. (2021). Gerakan Digital Mobilisasi Opini : Studi SNA \# Dirumahaja Vs . \# Pakaimasker. 6(1), 77-93.

Suharko, -. (2006). Gerakan Sosial Baru di Indonesia: Repertoar Gerakan Petani. Jurnal Ilmu Sosial Dan Ilmu Politik, 10(1), 1-34. https:/ / doi.org/10.22146/JSP.11020

Sulaeman. (2021). Menaker: 17,8 Persen Perusahaan PHK Karyawan Selama Pandemi Covid19. Merdeka.Com. https://www.merdeka.com/uang/menaker-178-perusahaanphk-karyawan-selama-pandemi-covid-19.html 